\title{
Narratives of emergence: Rising powers and the end of the Third World?
}

ANDREW HURRELL*

This article examines recent arguments from development economists, from historians and from international relations specialists that do challenge the continued relevance of the idea of the Third World. It then examines five reasons why these arguments are wrong. We can indeed understand much about emerging powers in terms of how they are seeking to navigate and best position themselves within an existing state-centric, liberal and capitalist order whilst accepting many of the underlying assumptions and values of that order. But the nature of that navigation has been shaped by their historical trajectory and by the developmental, societal and geopolitical context of their emergence.

Keywords: BRICs; Global South; Third World; Emerging Powers.

JEL classification: F02.

Debates about the diffusion of power and the emergence of new powers have become ubiquitous. But even a cursory reading of the policy debates, the popular literature, and the steadily-growing volume of academic work reveals that there are many unanswered and unresolved questions. Some relate to the nature of power. Others relate to the range of very different understandings of the global order into which today's emerging powers are said to be emerging. But another set of questions - and the subject of this article — has to do with the political groupings, spatial categories and taken-for-granted historical geographies that shape both academic analyses and political understandings of emerging powers.

One of the most important issues concerning today's emerging powers is the impact that their rise may be having on the concepts of the Third World and the

\footnotetext{
"Andrew Hurrell is Montague Burton Professor of International Relations and Fellow of Balliol College, Oxford. E-mail: andrew.hurrell@nuffield.ox.ac.uk. Submitted: 18/September/2012: Approved: 5/ December/2012.
} 
Global South and on the very idea of North/South relations as a structuring feature of the international system. Do the rise and increasingly influence of major developing states bring North/South relations back to the centre-stage of international relations? Or does the appearance of countries such as China, Brazil, India and South Africa around the top tables of global governance simply add one more argument to the essential irrelevance of the South or Third World as meaningful categories of political action and academic analysis?

It has become common to suggest that the rise of new powers, the developmental gap that has opened up between them and other developing countries, and their very different power-political, military, and geopolitical opportunities and options simply underscore the out-datedness and irrelevance of old-fashioned notions of the Third World or the Global South. Their success places them in an objectively different analytical category from other developing countries. They are emerging powers partly by dint of their sheer economic size but also because of ideas that stress their (often historically frustrated) right to be recognized as major powers and by foreign policies that aim ever more directly at increased power, influence and prestige.

Thus, in terms of development policy, Paul Collier makes the following claim.

The Third World has shrunk. For forty years the development challenge has been a rich world of one billion facing a poor world of five billion people. The Millennium Development Goals established by the United Nations, which are designed to track development progress through 2015 encapsulate this thinking. By 2015, however, it will be apparent that this way of conceptualizing development has become outdated. Most of the five billion, about 80 percent, live in countries that are indeed developing, often at amazing speed. The real challenge of development is that there is a group of countries at the bottom that are falling behind, and often falling apart. (Collier 2008: 3)

Looking more broadly, Robert Zoellick also argues for the 'end of the Third World':

If 1989 saw the end of the 'Second World' with Communism's demise, then 2009 saw the end of what was known as the 'Third World': We are now in a new, fast-evolving multi-polar world economy - in which some developing countries are emerging as economic powers; others are moving towards becoming additional poles of growth; and some are struggling to attain their potential within this new system where North and South, East and West, are now points on a compass, not economic destinies. (Zoellick, 2010)

If poverty, weakness and political marginalization defined the Third World, something important seems to have changed. 'The salient feature of the Third World was that it wanted economic and political clout. It is getting both' (The 
Economist, 2010: 65). On the back of such a view come calls for major emerging powers to jettison claims for special treatment or special status - in terms of the trading system they should 'graduate' from the developing country category; in terms of climate change they should not hide behind the Kyoto Protocol's principle of 'common but differentiated responsibility'; and in terms of human rights they should no longer invoke outdated third-worldist conceptions of hard sovereignty as a reason for inaction. In other words, they should no longer use under-development, poverty, a prior history of colonialism or historical marginality as 'excuses' to evade assuming their 'responsibilities' as emerging major powers. ${ }^{1}$

If one set of arguments looks to overall economic and political outcomes, a second set focuses on the specific historical claim that the Third World should be seen either as a product of the Cold War or at least very closely connected to the character and dynamics of the Cold War. The Third World, on this account, was a historical construction of the period that ran roughly from the Bandung Conference in 1955 to the onset of the Latin American debt crisis in $1982 .{ }^{2}$ Central to almost all understandings of the Third World in this period was a particular view of the politics of underdevelopment. ${ }^{3}$ Conceptualizations of the Third World centred on a range of state-building and development projects on the part of those states and governments seeking to end poverty, weakness and vulnerability, to overcome the legacies of colonialism, and to lessen or overcome the constraints created by the international political system, by international institutions and, above all, by global capitalism. ${ }^{4}$ Debates on economic development were in some ways complex and endlessly variegated. ${ }^{5}$ But they were essentially framed historically by the apparent success of Soviet-style forced industrialization on the one hand and by western Keynesian orthodoxies on the other, both of which, of course, fell victim to the end of the Cold War.

The Third World can also be understood as a specific kind of foreign policy project - one that saw independence and autonomy as dominant goals and took Third World solidarity and Third World coalitional politics to be the best means of achieving those goals. But, on this view, it is impossible to understand this project outside of the interventionism of the Cold War years and the ideological struggles of the superpowers in the Third World. Superpower competition was instrumental in maintaining otherwise frail post-colonial states and in helping to cover their manifold domestic weaknesses and injustices. Finally, the Cold War created

\footnotetext{
${ }^{1}$ See, for example, Rachman (2010).

${ }^{2}$ Westad (2006).

${ }^{3}$ For a classic statement that stresses colonialism, poverty, populist mobilization, and non-alignment see Worsley (1964).

${ }^{4}$ For three different perspectives amongst the very large literature analysing the idea and evolution of the Third World and of the South see Payne (2005, especially pp.3-11); Prashad (2007) and Rao (2010, especially pp.24-30).

${ }^{5}$ For an excellent account see Murphy (2005).
} 
and enshrined a particular political and normative framing of the Third World, including on the part of many groups within the First World. This framing viewed the revolutionary struggles of the 1960s and 1970s as a focal point for the onward march of history. If the Third World was a zone of war and imperialist oppression, it was also a zone of actual and potential revolutionary change. ${ }^{6}$

The Third World movement, as it developed from the mid-1950s to the early 1980s, was therefore never simply about shared economic characteristics, but was rather a political project that was built on the shared experience of marginalization and that aimed at reducing vulnerability to external forces and factors, whether of superpower intervention or of global capitalism. For the Third World, the ideological claims of both superpowers were hollow and self-serving. The moral legitimacy of non-alignment and third-worldism rested precisely on the repudiation of the bloody interventionism of both superpowers in the so-called 'periphery' constituted by the post-colonial world.

By the early 1980s, however, the apparent cohesion of the Third World coalition that had brought the western countries to the negotiating table to talk about a New International Economic Order (NIEO), had been undermined. It had been undermined by the increased differentiation across the developing world (especially the rise of the Asian Newly Industrializing Countries); by the strains within the coalition itself; by the loss of sympathetic interlocutors within the North open to Southern demands; by the hard-line rejection of any idea or notion of a North/ South dialogue on the part of United States and its major allies; and by the deteriorating economic and political position of much of the developing world that accompanied the devastating financial and economic crises of the 1980s. The reformist rhetoric of the NIEO had been both defeated and deflated. Power-centred accounts of North/South relations stressed the existence of a 'structural conflict' reducible to contending sets of power and interest - however encrusted within the empty rhetoric of justice. ${ }^{7}$ The powerful neo-liberal critique of rent-seeking southern elites cut deep into progressive third-worldism. On the left, post-colonial writers came over more to view the post-colonial state with deep disdain and the progressivist narratives of both capitalism and communism with even greater scepticism. And critical political economists argued that, to the extent that developing countries 'emerged', it would be as the result of structural changes in patterns of capitalist global production and the spread of neo-liberal ideologies

In so far as it survived, the Global South came to be defined in transnational social terms rather than as a grouping or category of nation-states. ${ }^{8}$ Empirical accounts focused more and more on the social movements that were emerging within and across the Global South in response to neo-liberalism. Normative attention was also shifting away from Southern states and towards social movements and civil society groups within the Global South: the World Social Forum (WSF), anti-global-

\footnotetext{
${ }^{6}$ Hobsbwam (1994).

${ }^{7}$ Krasner (1985).

${ }^{8}$ See Slater (2004).
} 
ization groups, post-Seattle protest movements. The idea that the WSF represented the 'New Bandung' precisely captured this shift — away from states and towards different forms of social movements in which the idea of the South as both a focus of protest and a transformative project lived on but in a radically different form. ${ }^{9}$

If the Third World had a hard time surviving the end of the Cold War, we might say that it was kept in business only as a response to United States power, to neo-liberal hegemony and to the manifold inequalities of so-called liberal globalization. On this view, global politics continued to be characterized by a series of overlapping but distinct hierarchies whose interaction reflected and affected both the possibilities of economic developing and the direction and character of international politics. Thus it could still make sense to think in terms of a structured pattern of global inequalities between an advanced, industrialized North and a poorer, weaker, less developed South and to use this framing to make a range of theoretical and analytical claims - for example, the way in which security is understood within the South (focused on internal insecurities and regime-survival), or the nature of the foreign policy preferences and interests of Southern states (driven by the need to minimize vulnerability and to maximize autonomy). But the increasing foreign policy influence of today's emerging powers, their relative success as relatively coherent states and fast-developing societies, and their economic dynamism and ever deeper integration into an ever more globalized capitalist order all conspired to represent a more decisive change and challenge to the inherited categories of Third World and Global South.

A third set of arguments frames this trajectory in analytical rather than in historical terms. It argues that we can best understand today's emerging powers in terms of universal categories of social analysis, all of which deny or downplay the role of historically specific claims to identity or difference. All of them, in their different ways, feed into the argument that the Third World is dead. For many liberals, the Third World and the South remain relevant but only as hold-outs from an earlier era and as loci of resistance to the positive, homogenizing and integrating logics of the western global liberal order. For realists, the essential division is between those that have the power to count as players in the game of power politics and those who do not. In so far as emerging countries are indeed 'powers', their role has fundamentally changed. And for neo-marxists, although inequality and stratification remain of vital importance, the notion of a South consisting of nationstates, whether fast-growing or not, simply confuses the true character of global politics in an era of globalized capitalism. Let us look very briefly at each in turn.

\section{EMERGING POWERS, GLOBALIZATION AND INTEGRATION}

The first narrative is about globalization, integration and convergence. It is an old story with roots in the debates of the 18th century, but came to dominate the

\footnotetext{
${ }^{9}$ Hardt (2002).
} 
debate about emerging powers for much of the post-Cold War period. In the 1990s global order was widely understood through the lens of liberal internationalism or liberal solidarism. Globalization was rendering obsolete the old world of Great Power rivalries, balance of power politics and an old-fashioned international law built around state sovereignty and strict rules of non-intervention. Bumpy as it might be the road seemed to be leading away from Westphalia - with an expanded role for formal and informal multilateral institutions; a huge increase in the scope, density and intrusiveness of rules and norms made at the international level but affecting how domestic societies are organized; the ever greater involvement of new actors in global governance; the moves towards the coercive enforcement of global rules; and a fundamental change in political, legal and moral understandings of state sovereignty and of the relationship between the state, the citizen and the international community.

Academics, especially in Europe and the United States, provided three kinds of liberal accounts of what was happening. Some stressed institutions and the cooperative logic of institutions. Institutions are needed to deal with the ever more complex dilemmas of collective action that emerge in a globalized world. As large states, including large developing states expanded their range of interests and integrated more fully into the global economy and world society -as they 'joined the world' in the language of the time - they would be naturally drawn by the functional benefits provided by institutions and pressed towards more cooperative and 'responsible' patterns of behaviour. The process would be neither easy nor automatic, but the broad direction of travel appeared to be clear. Others stressed the Kantian idea of the gradual but progressive diffusion of liberal values, partly as a result of liberal economics and increased economic interdependence, partly as a liberal legal order comes to sustain the autonomy of a global civil society, and partly as a result of the successful example set by the multifaceted liberal capitalist system of states.

A third group told a US-centred story. The US was indeed the centre of a unipolar world. But, true both to its own values but also to its rational self-interest, Washington would continue to bind itself within the institutions that it had created in the Cold War era in order to reassure smaller states and to prevent balancing against US power. For others, stability depends on the idea of strategic restraint and the role of institutions in signalling that strategic restraint. A rational hegemon will engage in a degree of self-restraint and institutional self-binding in order to undercut others' perceptions of threat. ${ }^{10}$ In return for this self-binding and the procedural legitimacy it would create and in return for US-supplied global public goods and the output legitimacy that they would create, other states would acquiesce and accept the role of the United States as the owner and operator of the system.

The challenge of the Second World had already been seen off. Now, through

${ }^{10}$ Ikenberry (2001). 
a mix of these three processes, those states of the old Third World that had previously challenged the western order would now become increasingly enmeshed, socialized and integrated. The 1990s, then, were marked by a clear sense of the liberal ascendancy; a clear assumption that the US had the right and power to decide what the 'liberal global order' was all about; and a clear belief that the western order worked and that it had the answers. Yes, of course there would be isolated rogues and radical rejectionists. But they were on the 'wrong side of history' as President Clinton confidently proclaimed.

Two further points can be noted. First, the concept of emergence itself developed out of precisely this set of ideas. The Brics, after all, were an invention of Goldman Sachs and 'emergence' was seen essentially as a market-driven phenomenon that reflected both deep changes in the structure of the global economy and making the 'right' economic policy choices. ${ }^{11}$ Modernization theory was back in fashion with its stress on the uniform and linear nature of development and its emphasis on the deep linkages between economic development, political democracy and societal modernization. ${ }^{12}$ And second, the nature and dynamics of power were changing in ways that would reshape what it meant to 'emerge' and to have 'power'. Soft power would outstrip hard coercive power in importance and concentrations of liberal power would attract rather then repel or threaten. Just as the example of a liberal and successful EU had created powerful incentives on the part of weaker and neighbouring states towards emulation and a desire for membership, so, on a larger scale and over a longer period, a similar pattern would be observed in the case of the liberal, developed world as a whole. A new raison de système would emerge that would alter and ultimately displace old-fashioned notions of raison d'état.

\section{THE RISE AND FALL OF GREAT POWERS}

For others, of course, the history and theory of emerging powers is simple and straightforward. International Relations has always been a story of the rise and fall of Great Powers, and will remain so. Classical realists, neo-classical realists, neorealists and power transition theorists differ as to whether conflict derives more from the actions of revisionist power seeking to remake the rules of international order or from the status quo powers anxious to preserve their power. However, within the realist camp there is wide consensus that if new powers are to 'count' globally it will be exclusively through their impact on the global balance of power. International politics is, by definition, the politics of the strong. The categorizations reflect this view: 'revisionist powers', or 'emerging powers' or new 'leading re-

\footnotetext{
11 See, for example, Jérôme Sgard (2008).

12 See, for example, Ingelhart and Welzel (2009).
} 
gional states' or 'would-be Great Powers'.$^{13}$ The analytical task is to understand which new powers have the resources and the will to make a difference; exactly how the balance of global power is shifting; and what this implies for patterns of conflict and cooperation. These countries may well face immense domestic challenges but these challenges are better understood by looking at earlier rising powers (Germany, Japan, the United States) rather than to comparisons with other 'southern' or 'developing' states.

Lest this all sound very old-fashioned, realists contest the liberal view of the post-Cold War outlined above and can point to a large number of factors which have indeed pushed global order back in a broadly Westphalian direction. These have included: the renewed salience of security, the revalorization of national security, and a renewed preoccupation with war-fighting and counter-insurgency; the continued or renewed power of nationalism, no longer potentially containable politically or analytically in a box marked 'ethnic conflict' but manifest in the identity politics and foreign policy actions of the major states in the system; the renewed importance of nuclear weapons as central to major power relations, to the structure of regional security complexes, and in the construction of great power hierarchies and the distribution of seats at top tables; and finally the quiet return of balance of power as both a motivation for state policy (as with US policies in Asia) and as an element in the foreign policy of all second-tier states - not hard balancing and the building up of hard power. But soft balancing either in the form of attempts to explicitly de-legitimize US hegemony or to argue for alternative conceptions of legitimacy.

Still more important, as the 1990s progressed so economic globalization fed back into the structures and dynamics of a Westphalian state system rather than pointing towards its transcendence. The state as an economic actor proved resilient in seeking to control economic flows and to police borders, and in seeking to exploit and develop state-based and mercantilist modes of managing economic problems, especially in relation to resource competition and energy geopolitics. Most significant, the very dynamism and successes of liberal globalization was having a vital impact on the distribution of inter-state political power - above all towards the East and parts of the South. The global financial crisis fed into these changes, undermining western claims to technocratic and normative legitimacy. The crisis also shifted the balance of arguments back to those who stress the advantages of large, continentally size or regionally dominant states - states that are able to depend on large domestic markets, to politicize market relations globally and regionally, and to engage in effective economic mercantilism and resource competition.

Finally, the idea of major power clubs and of Great Power concerts came back into political fashion. Faced by the intractability of many international crises and

\footnotetext{
${ }^{13}$ Because of the emphasis on hard power, many neo-realists are very sceptical about the diffusion of power. See, most notably, Brooks and Wohlforth (2008).
} 
by the limits of its own power and of existing international institutions, the United States should, for many analysts, secure its own interests, reduce the range of its burdens, and share the costs of tackling shared challenges by negotiating a new set of bargains with major emerging and regional powers. This kind of thinking is visible in the language of forming new 'concerts' made up of varying groups and finding new ways of 'organizing for influence' in the new 'great game'. The chairs around the table would be rearranged and the table probably expanded. There would be a good deal of 'global á la cartism' — a mosaic of different groupings and a great deal of 'messy multilateralism'.

This kind of analysis implies a number of potentially important things for emerging power behaviour. In the first place, we would expect that securing entry into these formal and informal groupings of major powers will become one of the principal goals of emerging states and would-be major powers. Second, we would expect to see power and power-related interests as a dominant driver of emerging state behaviour, trumping identity claims. Thus, whilst India may not share Washington's desire for a close alliance, the rise of China made rapprochement with the United States highly desirable, if not unavoidable. Equally, Brazil's lauding of China as a strategic partner has given way to a more balanced approach in the light of Chinese market competition, the impact of Chinese financial policy, and China's doubts about supporting Brazilian claims for United Nations Security (UNSC) membership. Third, from this perspective, power will come increasingly to dominate the relations between emerging powers and the rest, again whatever the rhetoric of shared southern or regional identity. Patterns of dominance and dependence will re-emerge but now at this lower level.

Fourth, the realist would expect that today's emerging powers will use the normative potential of the system to increase their power and legitimacy. It is entirely natural that they will use the language of procedural and substantive justice in making claims for a greater role within international organizations (as with India and Brazil in the World Trade Organization (WTO). They will denounce attempts by established western powers to use international norms to further their own interest - for example as regards humanitarian intervention. But, from a realist viewpoint, their own policies need to be understood in similarly relativist and instrumentalist terms. They are behaving in essentially the same way as did the revisionist states of the 1930s, exploiting both their material power but also, and crucially, the moral resources of the system.

Finally, in so far as the more pessimistic expectations of this power-political view are avoided, this is likely to be the result, not of multilateralism but rather of successful major power accommodation. The co-option of today's emerging powers into this system, if it is to occur, will be a matter of major power (re)ordering. It will have nothing whatsoever to do with the sorts of justice claims made by the Third World in the 1970s, nor with the management of North/South relations in their classic sense. 


\section{EMERGING POWERS AND TRANSNATIONAL CAPITALISM}

The neo-marxist account has been neglected by mainstream western debate but can also be deployed to support arguments about the end of the South. On this view, an excessive focus on the emerging nation-states of the South clouds and confuses the issue. What we are seeing is, in reality, the transformation of global capitalism from an old core centred on the advanced industrialized states into a far more global and far more thoroughly transnationalized capitalist order. The systemic change has to do with the unfolding of a deterritorialized global capitalism made up of flows, fluxes, networked connections and transnational production networks, but marked by inequality, instability, and new patterns of stratification. Rather than count up and categorize the 'power' of emerging powers, the intellectual challenge is to understand the 'transnational whole' in which such countries are embedded and the social forces and state-society relations that give meaning to the national and developmental projects pursued by emerging country elites.

Old-style notions of North and South have therefore been rendered outdated.

Yet ... capitalist imperialism is considerably more complex under globalization than the facile North-South-core-periphery framework through which it is typically viewed. The class relations of global capitalism are now so deeply internalized within every nation-state that the classical image of imperialism as a relation of external domination is outdated. (Robinson 2007)

This sort of view picks up on earlier dependency analyses of an earlier period that also questioned the claims to autonomy of the rising developing economies of the 1970s but stresses the now far more strongly global and integrated nature of contemporary capitalism. It does not necessarily depend on a deterministic view of class interests. Instead it stresses the shifting balance of power between public institutions and private capital and a deep scepticism as to the claims of emerging powers to be seen as trailblazers of new forms of capitalist development that retain a national or nationalist orientation.

Unfortunately, return to "nationalist" projects does not deal with the fact that the predominance of private power over public institutions is as much a problem at the national level as it is at the global level. Private economic elites in the South may not be fully integrated into Robinson and Sklar's "transnational capital class", but differences between their economic agenda and that of capital based in the North seem to be increasingly marginal and diminishing over time. (Evans 2008: 283)

This form of analysis stands as an important analytical corrective to the crude focus on national power so prevalent in discussions of emerging powers; it directs our attention to the nature of state-society relations and to the evolving role of the state within transnational capitalism; and it highlights the continued reality of in- 
equality, poverty, and social exclusion in many parts of the developing world, including within emerging powers.

Each of these narratives can tell us something of importance about today's emerging powers. But they suffer from important limitations and weaknesses. Taken together these limitations suggest that we should be cautious before consigning ideas of the Third World and of the Global South to the dustbin of history.

The first reason for caution rests on a rather different reading of the history of the Third World. Whilst the Cold War was of immense importance for understanding the Third World, the history of the Third World cannot be reduced to the Cold War. Even during the period from the mid-1950s to the mid-1980s the Cold War was one of several explanatory dynamics. ${ }^{14}$ But, more importantly, the Third World movement itself needs to be set in a broader historical perspective. A central part of the problem of global order from the mid-19th century was the struggle of the non-western world, the Third World or later the Global South against what was widely understood as the western dominance of the international system - what Hedley Bull termed the 'revolt against western dominance'. ${ }^{15}$ And a central question about the idea of 'emergence' continues to revolve around the ways in which the rise of today's emerging developing countries may be said to constitute a challenge to this historically constructed western order. On this account, the calls for an NIEO in the 1970s represented only one element in a much broader historical story, involving the struggle for equal sovereignty, for decolonization, for racial equality and for an equality of cultural status.

Critical and post-colonial scholarship has helped to challenge both the idea of an easy dichotomy between the 'West' and the 'Non-West' and also the confident and complacent image of a global international society created via the universalization of essentially European institutions and European understanding of modernity. Such work has underscored the extent to which the 'West' was itself formed through its long (and extremely conflictual) engagement with the non-western world; the need to consider the concrete social and political struggles through which western ideas of international order were transposed into different national and regional contexts; ${ }^{16}$ and the extent to which the categories of European thought are themselves implicated in the production of a world of hierarchy and domination, however much the specific subjects of domination may be shifting. ${ }^{17}$

Nevertheless it is the intertwining of national and imperial power, of industrialization and western economic success, and of cultural and civilizational hierarchy that sets the crucial historical backdrop for understanding the long-delayed 'emergence' of the non-western world. The 19th century was already full of debates

\footnotetext{
${ }^{14}$ See Ian Roxborough's review of Westad, The Global Cold War, American Historical Review 112, 3 (2997: 806-808).

${ }^{15}$ Bull \& Watson (1985).

${ }^{16}$ Colas (2002: 108).

${ }^{17}$ Chakrabarty (2000).
} 
about the changing nature of power and the impact that industrialization and modernization would have on the scale of social and economic organization. There was an endless discussion of the powers of the future. Thus Toqueville famously pointed to the rise of Russia and the United States. Liberals such as Cobden were convinced that England had to repudiate both empire and its Palmerstonian fixation on the European balance of power so as to be able to compete with the rising powers of the future - Russia and, above all, the United States. Imperialists such as Seeley were equally convinced that it was only through empire and the creation of a 'global state' that England could prosper both materially and morally in a world in which Russia and America 'would be on altogether higher scale of magnitude'. ${ }^{18}$

Nineteenth century ideas about the changing scale of material power were never just about power and material capabilities. Alongside discussions of the impact of the Industrial Revolution there ran a continuous preoccupation with moral, cultural and civilizational factors. These played a crucial role in determining the status of 'great nations' and who was to count in the international pecking order of the future. Within Europe, Marx, Mill, Hegel and many others all believed in a hierarchy of nations with only some possessing the necessary moral character and the historically progressive potential. ${ }^{19}$ But it was in relation to the non-European world that differentiation and hierarchy were clearest: hence the widely-held belief in the concept of civilization and in a hierarchy of races; $;{ }^{20}$ hence the elaborate debates as to the principles, criteria and 'standards of civilization' by which nonEuropean states might be able to be accepted as sovereign members of the 'society of states' or the 'family of nations'; ${ }^{21}$ and hence the idea of Europe as the unique sight of a universal and universalizing modernity, in which, as David Ludden suggests, the economic divergence between Europe and the rest soon became a 'global cultural phenomenon'. ${ }^{22}$

It is important to note the legacy of 19th century ideas about civilizational hierarchy and the way in which they lived on in the hegemonic presumption of the western world through much of the 20th century. For example, the close links between European geopolitical thought and mid-20th century American realism are well known, above all in the work of Nicholas Spykman. However the overt role of racial hierarchy and civilizational difference that had been central to European geopolitical thinking gets downplayed as it crosses the Atlantic. But race and civilization are submerged rather than wholly dislodged until they reappear once

\footnotetext{
18 See Duncan Bell (2007).

${ }^{19}$ See Varouxakis (2007:136-158).

${ }^{20}$ For recent treatments see MacCarthy (2009) and Bowdon (2009. See, more generally, Hobson \& Sharman (2005).

${ }^{21}$ Gong (1984).

${ }^{22}$ Ludden (2002: 470).
} 
more with full force in their Huntingtonian incarnation and the invocation of clashing civilizations. Thus, for example, Kennan's view of the regions and states that 'mattered' geopolitically was never a purely clear-headed analysis of the five centres of material power and his assessment of the likely (non-)development of the Third World was clearly shaped by a view of western cultural superiority and his own crude racial attitudes. ${ }^{23}$ And, whilst Kissinger was fascinated with China's civilization, he was equally crudely dismissive of most of the developing world, not just as a region without power, but as a region without history. 'Nothing important can come from the South... The axis of history starts in Moscow, goes to Bonn, crosses over to Washington, and then goes to Tokyo. What happens in the South is of no importance. 24

So what does this imply for the analysis of emerging powers today?

In the first place, there remains a commonality if not directly in terms of the challengers then certainly in terms of the target of that challenge. From this perspective the crucial point is that we are witnessing a challenge to the 'West'. Sometimes the focus is on the West as a historical formation built around the history of European power and its colonial system that was then inherited, transformed and globalized by the United States. Sometimes the focus is narrower - on the Euro-Atlantic world or even the Anglo-American world or Anglosphere. Sometimes arguments centre on the US-centred Greater West and the multilateral institutions created in the post-1945 period. The language is everywhere ill-defined and fuzzy. The widespread use of inverted commons - the 'West', the 'developing world', the 'Rest' - suggests hesitancy or uncertainty. But the ubiquity of this kind of language implies that what fundamentally distinguishes today's emerging powers is their historic position outside, or on the margins of, some notion of the West.

Second, we need to ask about the legacy of historical perceptions of secondclass treatment, of subalternity, of marginalization and of subordinate status within an unequal and exploitative global political and economic system. And a central element of Third World foreign policies was the demand for status, for recognition and respect. Alfred Sauvy's original coining of the idea of the Third World concluded with precisely this idea: 'For, in the end, this Third World, little known, exploited, scorned like the Third Estate, itself wants to be something (Sauvy 1952: 14). The emphasis on hard sovereignty and the need for status and recognition on the part of China, India, or Brazil may reflect the common experience of large, continental sized states with exceptionalist histories - rather than the imperatives of weakness and post-colonial statehood. But those histories also underpin a struggle for recognition and for recognition of being different rather than of becoming the same; they open the possibility that although the surface language of power may appear similar, that language contains distinctive features.

A second reason for not equating the end of the Third World with the end of

\footnotetext{
${ }^{23}$ See Stephanson (1989, especially pp.157-175).

${ }^{24}$ Remarks to the Chilean ambassador in 1969, quoted in Seymour Hersh (1983: 263).
} 
the Cold War looks not backwards in time but rather to those factors that link the 1970s and the contemporary period. Here it is important to see just how closely the dynamics of emerging powers today were directly the products of western responses to power diffusion and relative power decline during the previous 'crisis of the West' in the 1970s. Commentators at that time pointed to the diffusion of power and the challenge posed by the Third World to western order; to the way in which North/South cleavages were shaping the politics of new global issues such as the environment, resource scarcity and nuclear non-proliferation; to the tensions within the capitalist core as the Keysenian orthodoxy unravelled in the face of social conflict, low growth and high inflation; and to the debates surrounding the hegemonic decline of the United States. ${ }^{25}$

After dallying with the possibility of serious negotiations around a North/ South dialogue, the dominant response was two-fold. One major response to declining US and western hegemony was to foster, encourage and enforce an aggressive phase of liberal globalization, especially of financial globalization. And yet it was precisely the particular character of economic globalization and the debt-fuelled growth that helped to create the conditions both for the successful emerging economies of today and for the current challenges to US and western power and authority. The other central feature of the US policy in the 1970s was to revive a policy of active and aggressive interventionism in the South as part of the Second Cold War. Again, whilst this may have been a successful element in the victory of the West in the Cold War, it also helped to foster, or deepen, or shift the character of many of the conflicts that are proving so intractable to Washington today, especially in relation to the Islamic world. Seen in terms of both these responses the long-1970s become more important in understanding where we are today; and the end of the Cold War rather less so.

A third reason for believing that the idea of the Third World remains of some relevance to our understanding of today's emerging powers has to do with coalition politics. For writers such as Robert Rothstein, the Third World of the 1970s was never about shared attributes or legacies of colonialism or particular statist projects of development. ${ }^{26}$ It was rather about an instrumentally driven set of coalitional politics. It constituted a diplomatic reality. From this perspective it is important to underscore the southern character of the foreign policies of today's emerging powers, the extraordinary growth in South-South trade and economic ties (radically different from the 1970s) and the formation and persistence of southern coalitions such as the trade G20 within the WTO or groupings such as the Brics (especially after South Africa joined in April 2011) or the IBSA Trilateral Forum of India, Brazil, and South Africa created in 2003.

It is certainly the case that, as realists would predict, differences have appeared within the South. On climate change, for example, there have been significant dif-

\footnotetext{
${ }^{25}$ See Ferguson et. al. (2010).

${ }^{26}$ Rothstein (1977).
} 
ferences between the BASICs and other developing countries. At Copenhagen, the entry of the BASICs into the closed councils of the most powerful caused intense resentment on the part of countries such as Bolivia. At Durban, the representatives of small island developing states were still more critical of an India that seemed to stand in the way of a final deal. ${ }^{27}$ Nevertheless, the recent forms of Southern multilateralism led by today's emerging and regional powers have put the idea of the Global South back on the political and intellectual map. ${ }^{28}$ As a result, and especially following the financial crisis and the creation of the G20, we are seeing an ever more open and dynamic series of negotiations between North and South over the nature and agenda of global governance. In addition, southern coalitions may persist not because of any meaningful shared identity or even concrete interest but because of bureaucratic inertia within international organizations - as for example in the process by which memberships and directorships of International Organisations are decided. In the world of formal multilateralism, after all, the G77 is very much alive.

A fourth factor has to do with the distinctiveness of today's emerging powers. Even if we place China in a category of its own, countries such as India, Brazil and South Africa are large developing countries that will continue to be relatively poor in per capita terms. Poverty and inequality remains major problems and high growth rates remain a major political imperative. For all their economic success, they remain developing economies and developing societies marked both by incomplete development and by incomplete integration into a global economy whose ground-rules have been set historically by the industrialized North. Moreover a great deal depends on our assessment of the nature and extent of developmental gains and of the actual power shifts that are taking place. It is easy to exaggerate the emerging powers and the extent of the power shift that has taken place. Yes, China, India and Brazil have indeed acquired veto power within the WTO; yes, changes are underway in the voting structures and governance arrangements of the International Financial Institutions (IFIs); and yes, the creation of the G20 does represent an important change in the nature and membership of the top table. But these changes are, thus far, hardly revolutionary. Developmental policy space remains restricted by the current rules of the global game. As a result, there remain many areas of common interest and common concern amongst a broad range of developing countries which remain rule-takers far more than rule-makers. ${ }^{29}$

A fifth and final factor concerns the continued relevance of North/South relations for the framing of global problems and the extent to which this framing helps to structure the interests of emerging powers. Climate change again provides an

\footnotetext{
${ }^{27}$ Although focused on climate change, the following analysis of intra-emerging power relations captures both the differences but also the forces of convergence. Karl Hallding, Marie Olsson, Aaron Atteridge, Antto Vihma, Marcus Carson and Mikael Román, Together Alone. BASIC Countries and the Climate Change Conundrum (Copenhagen: Tema Nord, 2011).

${ }^{28}$ See, in particular, Alden and Vieira (2011).

${ }^{29}$ See Robert Wade (2011: 347-378).
} 
important example. Hence it may indeed be the case that BASICs have been tempted to stress their special responsibilities and to join clubs or groupings of major emitters, even if, as at Copenhagen, this opens up major divisions with other developing countries. It is also true that emerging southern powers complicate the simple normative picture of a world divided simply between a rich and powerful North and an impoverished and marginalized South - in terms of the aggregate contribution of their societies to the problem, in terms of their capacity as states and societies to contribute in financial and technological terms to solutions, and in terms of the moral relevance of unequal patterns of wealth and resource use within them. But it remains very hard to think about climate change outside of the context of inequality, poverty and the developmental imperatives of large developing countries. It may be technically or technologically possible to imagine dealing with climate change without considering inequality and global poverty. But, from a wide range of moral viewpoints, it would be wholly unacceptable to deal with climate change in a way that would worsen the welfare and life-chances of the currently poor; that would fail to provide sufficient developmental and ecological space for these poor to satisfy their rights to reasonable standards of subsistence and well being; and that would undermine or close off the developmental prospects for the poor of future generations. It is for this reason that it matters normatively that emerging developing countries are able to shift the distribution of power and to place a broader range of moral issues on the global agenda - the importance of representation and of 'democratizing' international institutions, the role of differential needs in trade negotiations, and the role of historical and current inequalities in assigning responsibilities within a climate change regime.

I began by noting how the rise of today's emerging powers has challenged many common assumptions about world politics and destabilized many of the taken-for-granted political groupings, historical geographies and spatial categories that have shaped both academic analysis and political understandings. Notions of 'West', 'North', 'South', 'Third World' are fluid, elusive, and ever harder to define. In many cases they seem to make no obvious sense. How can the idea of the South cope with the tremendous heterogeneity of economic performance, state-capacity, social coherence and geopolitical power that now exists across the so-called 'developing world'? What possible sense can it make to see Brazil and Latin America as challengers to the 'West'? And to resort to the vacuous notion of the 'Rest' is simply to avoid the issue.

For some it is therefore obvious that we should seek to analyse emerging powers in terms of broad, universal categories. The three narratives of emergence sketched in the second section involve claims to provide the intellectual resources to understand both the drivers of emerging state behaviour and the ways in which we might best understand the places of these countries in the world. In some cases these claims rest on some universal, or at least very broadly based, social category, whether interest, power or class. In other cases, the claim for stable categorization rests on a particular view of history and of the direction of history.

Nevertheless, the limits of each of the three narratives and the extent to which 
both analysts and practitioners cannot avoid the messy categories of 'South', 'West', 'North' also tells us something important. As I have suggested, the notion of a Global South remains relevant for understanding the specific (but varying) identities of major emerging powers, the ways in which these identities are the product of particular histories and socio-historic worldviews and shape more specific interests, and how many within the emerging powers understand the target of their challenge. We can indeed understand much about emerging powers in terms of how they are seeking to navigate and best position themselves within an existing state-centric, liberal and capitalist order whilst accepting most of the underlying assumptions and values of that order. But the nature of that navigation has been shaped by their historical trajectory within that order and by the developmental, societal and geopolitical context of their emergence.

In terms of the contemporary analysis of emerging powers, it becomes very important to resist binary distinctions and lazy dichotomies. The impact of globalization on emerging states and societies has all too often been conceived in polar terms - incorporation vs. exclusion; fusion vs. fragmentation; modernizing, liberalizing coalitions vs. confessional, nationalist or third-worldist counter-forces. Of course, almost all discussion of globalization recognizes that its impact is highly uneven, as some parts of the world are incorporated into ever denser networks of interdependence whilst other regions are left on, or beyond, the margins. Equally, almost all writers stress the extent to which globalizing forces may produce fragmentation, reaction, or backlash. But to think principally in these polar terms has been to obscure what is most interesting: that, whilst powerful systemic pressures exist, both processes of change and, more important, outcomes vary enormously. The character and intensity of globalizing pressures depend on geopolitical position, level of development, size, and state strength. Perhaps most crucially in very large, enormously complex, fast-developing states, systemic and global pressures come up against powerful inherited domestic structures and historically embedded modes of thought. It is important, then, both to acknowledge and to analyze the systemic pressures but, at the same time, to unpack and deconstruct the complex processes of break-down and adaptation that have taken place, and to do so in a way that plays close attention to the complex struggles for power both between and within emerging societies.

Patterns of binary thinking are extremely unhelpful - analytically, normatively and politically. Instead the need is to understand the relation between the outside and the inside and to track the processes by which western ideas of international order and capitalist modernity have been transposed into different national and regional contexts and to the mutual constitution of ideas and understandings that resulted from that interaction. In some cases, perhaps most plausibly China, on-going integration may well involve a questioning or recasting of the fundamental social categories of western social thought - state, market, civil society. In other cases we need to be constantly alert to what Fernando Henrique 
Cardoso once labelled the 'originality of the copy'. ${ }^{30}$ And in many places, relations of space and time and belonging have shifted so that 'North' and 'South' co-exist simultaneously within the same geographical space. ${ }^{31}$ The mixed and hybrid character of the global order means that we need to be especially alert to the recombination of old and new not just at the level of global order but also at the level of the state and of state-society relations domestically. And here one might focus less on the BRICs as a group; and more on the intellectual and policy 'bricolage' - to use Mary Douglas's term — that has been taking place within each of the emerging states and through which old and new ideas and policies are melded together in ways that are working against these states becoming simply absorbable within some expanded version of a liberal Greater West. ${ }^{32}$

\section{REFERENCES}

Alden, Chris and Marco Vieira (2011) The South in Global Politics. Basingstoke: Palgrave.

Bell, Duncan (2007) The Idea of Greater Britain: Empire and the Future of World Order. Princeton: Princeton University Press.

Bowdon, Brett (2009) The Empire of Civilization: the evolution of an imperial idea. Chicago: University of Chicago Press.

Brooks, Stephen G. and William C Wohlforth (2008) World Out of Balance. International Relations and the Challenge of American Primacy. Princeton: Princeton University Press.

Bull, Hedley \& Adam Watson eds., (1985) The Expansion of International Society. Oxford: Clarendon Press.

Chakrabarty, Dipesh (2000) Provincializing Europe: Post-Colonial Thought and Historical Difference. Princeton: Princeton University Press.

Colas, Alejandro (2002) International Civil Society. Cambridge: Polity Press.

Collier, Paul (2008) The Bottom Billion. Oxford: Oxford University Press.

Douglas, Mary (1986) How Institutions Think. Syracuse: Syracuse University Press.

Evans, Peter (2008) 'Is an alternative globalization possible?' Politics and Society 36, 2.

Ferguson, Niall et.al. (2010) The Shock of the Global. The 1970s in Perspective. Cambridge MA.: Harvard University Press.

Gong, Gerrit W. (1984) The Standard of 'Civilization' in International Society. Oxford: Clarendon Press.

Hardt, Michael (2002) 'Today's Bandung?' New Left Review 14.

Harvey, David (2009) Cosmopolitanism and the Geographies of Freedom. New York: Columbia University Press.

Hersh, Seymour (1983) The Price of Power, London: Faber and Faber.

Hobsbwam, Eric (1994) Age of Extremes - The Short Twentieth Century, 1914-1991. London: Michael Joseph.

Hobson, John M. and Sharman, J. C. (2005) 'The Enduring Place of Hierarchy in World Politics: Tracing the Social Logics of Hierarchy and Political Change', European Journal of International Relations, 11.

\footnotetext{
${ }^{30}$ Hurrell (2010).

${ }^{31}$ On this theme see, in particular, David Harvey (2009, especially chapters 7 and 8).

${ }^{32}$ Douglas (1986).
} 
Hurrell, Andrew (2010) 'Cardoso and the World', in Herminio Martins and Maria Angela D'Incao eds., Democracia, crise e reforma. Estudos sobre a era Fernando Henrique Cardoso. São Paulo: Editora Paz e Terra.

Hurrell, Andrew (2010) 'Rethinking the "third world": Seeing the world differently', The Economist 12 th June 2010.

Ikenberry, G.J. (2001) 'American Grand Strategy in the Age of Terror', Survival 43, 4.

Ingelhart, Ronald and Christian Welzel (2009) 'How Development Leads to Democracy', Foreign Affairs, $88(2)$.

Krasner, Stephen (1985) Structural Conflict. The Third World against Global Liberalism. Berkeley: University of California Press.

Ludden, David (2002) 'Modern Inequality and Early Modernity', American Historical Review, 107, 2.

MacCarthy, Thomas (2009), Race, Empire, and the Idea of Human Development. Cambridge: Cambridge University Press.

Murphy, Craig N. (2005) Global Institutions, Marginalization and Development. New York: Routledge.

Payne, Anthony (2005) The Global Politics of Unequal Development, Basingstoke: Palgrave.

Prashad, Vijay (2007) The Darker Nations: A People's History of the Third World. New York: New Press.

Rachman, Gideon (2010), 'China can no longer plead poverty', Financial Times 25th October 2010

Rao, Rahul (2010) Third World Protest. Between Home and the World. Oxford: Oxford University Press.

Robinson, William I. (2007) 'Beyond the Theory of Imperialism: Global Capitalism and the Transnational State', Societies Without Borders 2.

Rothstein, Robert L. (1977) The Weak in the World of the Strong. The Developing Countries in the International System. New York: Columbia University Press.

Sauvy, Alfred (1952) 'Trois Mondes, Une Planète', L'Observateur 118, 14 August 1952.

Sgard, Jérôme (2008) 'What is an Emerging Country and Is it an Interesting Concept in the Social Sciences?', Global Insights.

Slater, David (2004) Geopolitics and the Post-Colonial. Rethinking North-South Relations. Oxford: Blackwell.

Stephanson, Anders (1989) Kennan and the Art of Foreign Policy. Cambridge: Harvard University Press.

Varouxakis, Georgios (2007) '"Great" versus "small”: size and national greatness in Victorian political thought', in Duncan Bell ed., Victorian Visions of Global Order. Cambridge: Cambridge University Press.

Wade, Robert (2011) 'Emerging World Order? From Multipolarity to Multilateralism in the G20, the World Bank and the IMF', Politics and Society 39, 3.

Westad, Odd Arne (2006) The Global Cold War. Third World Interventions and the Making of Our Times. Cambridge: Cambridge University Press.

Worsley, Peter (1964) The Third World. London: Weidenfeld and Nicolson.

Zoellick, Robert B. (2010) 'The End of the Third World: Modernizing Multilateralism for a Multipolar World', Woodrow Wilson Center for International Scholars, 14th April 2010. http://web. worldbank.org/WBSITE/EXTERNAL/NEWS accessed 7th June 2011. 